\title{
IMPORTANCE OF OAK AMBROSIA BEETLES IN PREDISPOSING COAST LIVE OAK TREES TO WOOD DECAY
}

\author{
Pavel Švihra' ${ }^{1}$ and Maggi Kelly
}

\begin{abstract}
Attacks by the oak ambrosia beetle (Monothrum scutellare) accelerated and increased the amount of wood decay in stems of downed coast live oak (Quercus agrifolia) trees. When permethrin insecticide was sprayed on oak bark surface, the ambrosia beetles produced only one-fourth as many galleries in the sapwood as compared to sapwood beneath the unsprayed bark surface. Although decay fungi initiated infection in oak in the absence of beetles, the amount of wood decay was much greater in trees with beetle activity. The ambrosia beetles deeply penetrated the sapwood and constructed extensive galleries that hastened wood decay by decay pathogens. The insecticide inhibited beetle attack and formation of egg galleries and greatly decreased the amount of wood decay.
\end{abstract}

Key Words. Coast live oak; Quercus agrifolia; sudden oak death; Phytophthora ramorum; ambrosia beetles; decay progression.

Coast live oak trees (Quercus agrifolia) are injured by as many as 297 insect species and 148 fungus pathogens in California, U.S. (Swiecki et al. 1997). Phytophthora ramorum is a major causal agent of sudden oak death disease (SOD) in coastal California forests (Rizzo et al. 2002; Rizzo and Garbelotto 2003). The conditions that predispose several oak species in the red oak group (Erythrobalanus), including Q. agrifolia, Q. parvula var. shrevei, and Q. kelloggii, to infection by P. ramorum are not completely understood. However, sequential symptoms of SOD [(exudation of sap on lower stems, attacks by oak bark beetles (Pseudopityophthorus pubipennis) and oak ambrosia beetles (Monothrum scutellare) near bleeding cankers, and production of Hypoxylon thouarsianum basiodiocarps that follows P. ramorum infection] have been well described (Švihra 1999a, 1999b; McPherson et al. 2000; Švihra 2001; Storer et al. 2002; Švihra 2004). Stem breaking of coast live oaks with SOD symptoms often occurs when the leaves are still green (Swiecki and Bernhardt 2003; Švihra et al. 2004). Such trees may become hazards. Tree wounding may precede wood decay (Filip 2001), with the extent of decay influencing the time of stem breakage. Decay is influenced by several factors, including wood and site characteristics, as well as a variety of physical disturbances (Kaarik 1974).

Ostry and Anderson (1998) studied the role of insects, woodpeckers, and Hypoxylon canker (H. mammatum) in the infection and decay processes on aspen (Populus tremuloides).
Both the amount of infection and wood decay were favored by (1) deep wounding in the xylem and (2) frequent wounding by cerambycid beetles, cicadas, tree hoppers, and woodpeckers. Although P. ramorum cankers typically do not penetrate the xylem of coast live oaks by more than $3 \mathrm{~cm}$ (1.2 in.) (Rizzo et al. 2002), galleries of oak ambrosia beetles penetrate the xylem to depths of 5 to $15 \mathrm{~cm}$ (2 to 6 in.) and may play an important role in wood decay. By comparison, $P$. pubipennis beetles penetrate the xylem much less deeply but enough to impede water transport in xylem vessels (Švihra et al. 2004). When the stems of coast live oak trees break, dense egg galleries of oak ambrosia beetles are often found deep in the sapwood, together with extensive early wood decay adjacent to such galleries. Near the height of oak stem breakage, fruiting bodies of Hypoxylon thouarsianum often are present on bark surfaces. The fruiting bodies of Inonotus andersonii may appear several months later.

With the foregoing considerations in mind, a study was conducted to determine whether construction of galleries and brood development by oak ambrosia beetles affected the infection process as well as the rate and progress of wood decay in coast live oak. Specifically, we wanted to compare decay progress and its severity after the infestation and subsequent brood development of M. scutellare was prevented or retarded by permethrin insecticide.

\section{METHODS}

The study was conducted in Miwok Park, located in the City of Novato, California. The park is situated in a rolling landscape covering 10 ha (24.7 ac) of forest area at elevations between 21 and $84 \mathrm{~m}$ (69 and $277 \mathrm{ft}$ ). The dominant overstory forest trees are coast live oak and California bay laurel (Umbellularia californica). California black oak (Q. kelloggii), madrone (Arbutus menziesii), and California buckeye (Aesculus californica) are scattered among the dominants. Associated shrubs and vines include manzanita (Arctostaphylos manzanita), toyon (Heteromeles arbutifolia), poison oak (Toxicodendron diversilobium), and honeysuckle (Lonicera hispidula). A survey conducted in the fall of 2001 showed that 17 coast live oaks and four California black oaks displayed SOD symptoms. Six coast live oaks near park trails were dying or dead and had to be removed, and the stems of eight trees broke in the forest some distance from 
park trails. The presence of the SOD pathogen was confirmed on five sampled coast live oaks in laboratories at the University of California Davis and the California State Department of Food and Agriculture, Sacramento.

\section{Tree Selection and Treatment}

On a steep northwestern slope about $50 \mathrm{~m}$ (165 ft) from Novato Creek, the stems of two coast live oaks that were infected with P. ramorum, broke on September 5, 2001 (Tree A) and September 18, 2001 (Tree B). The foliage of both of the recently fallen trees was green and remained so until midNovember 2001, after which the foliage rapidly turned brown. The stem on Tree A [ $46 \mathrm{~cm}$ (18.4 in.) diameter at break point] broke at $80 \mathrm{~cm}$ (32 in.) above the ground, and the stem on Tree B [49 cm (19.6 in.) diameter at break point] broke at $130 \mathrm{~cm}$ ( 52 inches) above the ground. The trees broke in an area where a high-density gallery system made by oak ambrosia beetles penetrated about $8 \mathrm{~cm}$ (3.2 in.) deep into the sapwood. The stumps of both trees showed grayish $\tan$ frass near their bases, few fruiting bodies of $H$. thouarsianum, and fresh and dried black exudate signifying infection by $P$. ramorum, the causal pathogen of SOD. The stems of both trees from the breakage point up to the height where small twigs were common did not show any exudate or evidence attack by bark or ambrosia beetles.

Starting above the point of stem breakage, each $12 \mathrm{~m}$ (39.6 ft) long stem section and one limb were divided and marked with a grease pen and surveyor's tape into six $2 \mathrm{~m}$ (6.6 ft) long sections on September 21, 2001. Then Tree A's second, fourth, and sixth and Tree B's first, third, and fifth sections were sprayed to runoff with Astro [permethrin (chemical name: cyclopropanecarboxylic acid, 3-(2,2dichloroethenyl) 2,2-dimethyl-(3-phenoxyphenyl) methyl ester)] at the rate of $4.6 \mathrm{~g}$ a.i./L, while the first, third, and fifth sections of Tree A and the second, fourth, and sixth sections of Tree B were not sprayed and served as untreated controls.

To monitor beetle development beneath the bark, three infested bolts [ $40 \mathrm{~cm}$ (16 in.) long; $20 \mathrm{~cm}$ (8 in.) diameter] were cut with a chain saw from a nearby downed coast live oak on September 21, 2001; again in May 9, 2002, two heavily infested bolts of the same size were cut from the limb of Tree A and one bolt from Tree B. The infested bolts were transported to a nearby yard [approximately $0.5 \mathrm{~km}$ $(0.3 \mathrm{mi})]$ from the experimental trees, where they were placed into separate rearing refuse cans and kept in the shade under conditions described by Švihra et al. (2004). When new generations of M. scutellare and P. pubipennis began to emerge from the bolts in containers on March 30 , 2002, and August 24, 2002, the sections designated for insecticide treatment were re-sprayed. Three sprayings were made to prevent oak ambrosia beetle attacks, allowing for comparisons of the extent to which suppression of their boring activity would affect development of wood decay.
Beginning on September 21, 2001, the experimental trees were visited bi-weekly (a total of 30 visits) to inspect their bark surfaces, photograph evolving changes and record any changes in foliage color, density of beetle attacks, bark cracking, growth of fungal fruiting bodies, cerambicid and buprestid attacks, appearance of $P$. pubipennis exit holes, and woodpecker foraging.

On November 5, 2002, a 5 cm (2 in.) wide crosssectional disk was sawed from the middle of each section, labeled as to tree section, and transported to a laboratory. Each disk was immediately placed in a vertical position next to a metric scale, and its cut area was photographed with Fujichrome film using a Nikon $35 \mathrm{~mm}$ camera fixed to a tripod whose distance from the disk(s) was constant to maintain the same scale for all photographs. The developed film was scanned into high-resolution images (tif format). The tif files were examined in ArcGIS software. The ruler imaged with each sample was used to determine the resolution for each image pixel. Image pixels were consistent in size, at $0.33334 \mathrm{~mm}$ on a side, or $0.111116 \mathrm{~mm}^{2}$. Each tree cross section (excluding bark) was delimited by onscreen hand digitization, as was the extent of discolored wood material. The area of wood in each cross section, and the area of wood damage for each cross section, was determined automatically by ArcGIS software (ESRI 2004) by measuring polygon size. The total area of wood and total area of wood discoloration were recorded and used in the statistical analyses discussed below.

Decaying wood was defined as visibly discolored and soft that advanced radially toward the pith (Figure1), followed by stained wood underneath that was a different color (a variety of pale or red-gray colors) from both decayed wood above and sound heartwood below. Sound wood was defined as apparently healthy wood of reddish color. Because all of the sections treated with permethrin showed wood staining that preceded advance and development of decay, the stained and decayed wood were combined into one category "decayed wood area in $\mathrm{cm}^{2}$." The disks were stored in a cool storage until the total number of oak ambrosia beetle galleries on both sides of each disk were counted to determine the extent of beetle attack and the disc circumference was measured.

\section{Weather Data}

Data from the Petaluma East A Weather Station and the Point San Pedro Weather Station [about 6 and 8 km [3.7 and $5 \mathrm{mi}$ ] from Miwok Park, respectively) were used.

\section{Data Analysis}

The extent of wood decay between sprayed and unsprayed sections was analyzed using Student's t-test. The attack densities (differences in gallery counts per disk in sprayed and unsprayed sections) were evaluated by one-way 
ANOVA. All statistical analyses were conducted using JMP Statistical Software for the PC (SAS Institute, Inc., Cary, NC). Data were square root-transformed when necessary to meet the assumptions of ANOVA.

\section{RESULTS AND DISCUSSION}

Only very light beetle activity, signified by formation of white frass on the bark surface of unsprayed upper sections, was evident on October 5, 2001. Then a heavy rain storm on October 30 washed the frass away and no new frass was detected. Therefore, we could only confirm that beetle boring began after the downed oaks were sprayed on September 21, 2001. The photographs of bark surfaces of sprayed and unsprayed sections (Figure 2) taken on September 27, 2002 (after emergence of secondgeneration ambrosia beetles peaked) reflect the effectiveness of insecticide treatment. The differences in frass volume on the bark surface are clearly visible: the sprayed sections are almost free of frass, indicating that beetle activity was reduced or had ceased completely. Thus, arborists managing coast live oaks infected with P. ramorum should include insecticide treatment to prevent ambrosia beetles' attack that weakens the stem, making it prone to break, while displaying healthygreen foliage (Švihra et al. 2004).

The significant effect of insecticide treatment is also reflected in counts of the total number of ambrosia beetle galleries per disk section. The unsprayed sections were colonized by higher numbers of galleries (84.5 \pm 20 ), than sprayed sections $(23.8 \pm 17.6)(P=$ 0.0002). Thus, untreated control sections had almost four times as many galleries as did the treated
Figure 2. Detail showing coast live oak bark surface differences in Monothrum scutellare activity at the borderline between sprayed and unsprayed bark surface. The insets represent $2 \mathrm{~m}$ (6.6 ft) long sections: $A=$ unsprayed control stem; $B=$ sprayed stem. 
sections. How closely the percentage of decay correlated with insecticidal treatment is shown in Figure 3. In untreated sections with smaller diameters, wood decay increased, whereas treated sections were free of decay. The extent of decay was correlated with the number of galleries and their depth of penetration into the sapwood. In the insecticide-treated sections (No. 5 and No. 6 in Figure 3), the total of 12 galleries that were found did not penetrate more than $5 \mathrm{~cm}$ (2 in.) into the sapwood. However, in the untreated control sections (No. 6 and No. 5), oak ambrosia beetles constructed 135 galleries, many of which penetrated to a $14 \mathrm{~cm}$ (5.6 in.) depth. This might explain why the top untreated sections were $79.6 \%$ (No. 6) and 100\% (No. 5) decayed, because the excavation of galleries initiated on opposite sides crisscrossed through the wood. The mean area of wood decay of untreated sections was about ten times larger than in insecticide-treated sections [357.93 \pm $81.5 \mathrm{~cm}^{2}\left(57.27 \pm 13.04 \mathrm{in}^{2}\right)$ for untreated control sections; $31.43 \pm 28.8 \mathrm{~cm}^{2}\left(5.03 \pm 4.61 \mathrm{in}^{2}\right)$ for permethrin sprayed sections; $\left.\mathrm{t}_{10}=8.234, P<0.0001\right]$. This study demonstrated that treatment of the bark surface of coast live oak with permethrin inhibited gallery production by oak ambrosia beetles and greatly reduced wood decay caused by the fungus pathogen associated with SOD.

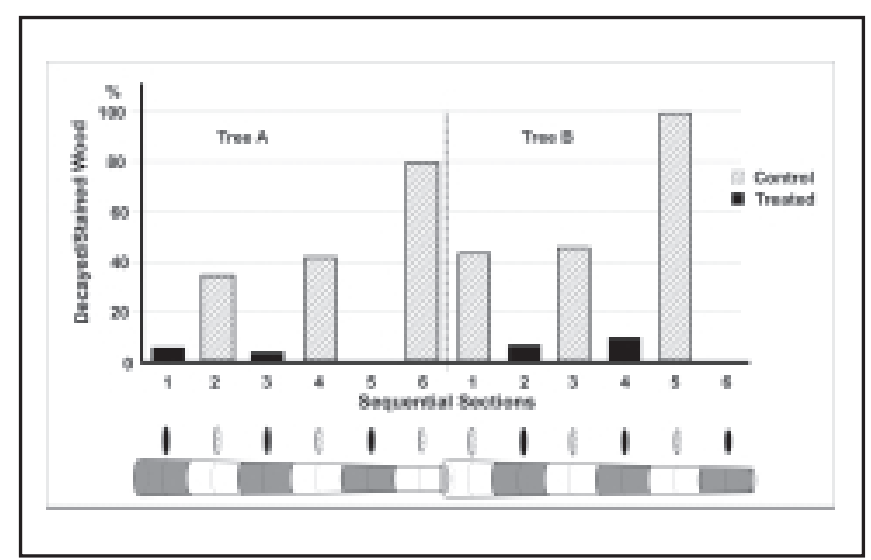

Figure 3. The extent of decay in the two $12 \mathrm{~m}(39.6 \mathrm{ft})$ long downed boles of Quercus agrifolia, each divided into six equal sections of which the bark surfaces of three sections were treated with permethrin insecticide and the remaining three sections were untreated controls.

Exit holes of P. pubipennis appeared only in untreated stem sections on April 5, 2002; the frass of buprestid and cerambicid attacks became visible on May 31 and continued until June 28 on both treated and untreated stem sections. Foraging by woodpeckers was detected only in the untreated control sections after August 9, when cracking of bark also became evident; and H. thouarsianum fruiting bodies were visible and abundant mostly on the bark surface of untreated controls on October 4, 2002.
Swiecki and Bernhardt (2003) stated that "ambrosia beetle boring was almost exclusively limited to the portion of wood that showed incipient to advanced decay." This implies that oak ambrosia beetles attacked after the decay developed. However, ambrosia beetles do not use wooddecomposing mycelium as a source of nutrition. Both the adults and larvae feed on Monilia brunea fungus, also known as "ambrosiella." Attacks occur only if the moisture content of wood is favorable when this "black fungus" is introduced and grows in gallery walls (Švihra 1999a). Ambrosia fungus gardening by ambrosia beetles (Raffaelea and Ambrosiella) arose some 200 million years ago (Farrell et al. 2001). However, it is not clear how the ambrosia fungus contributes to the breakdown and degradation of oak wood after the brood emerges. The biology of oak ambrosia beetles as primary invaders of stressed and dying trees and their function in the decay process were described by Bright and Stark (1973) and Furniss and Carolin (1978). Ambrosia beetles in general provide elaborate parental care to their offspring's survival, which involves two biologically significant components: the female inoculates associated ambrosia fungus on the gallery walls, and both the male and female beetles clean off frass in an expanding gallery system, thus regulating humidity and oxygen supply for ambrosia fungus growth as a larval food supply. Griffin (1977) classified decomposition fungi as obligate aerobes, with wood decay rates depending on availability of oxygen to these fungi. This study showed that acceleration of sapwood decay is a consequence of interplay between the boring activity of oak ambrosia beetles and excessive decay. Galleries must be free of boring dust to provide oxygen for developing offspring as well as for wood-decaying fungi. Additionally, as the males push frass outside and then return, they may transport wood-decaying fungal spores deep into the wood. Such parental care of fungus gardening lasts from 3 to 4 months. When beetle activity was prevented by permethrin in the present study, the wood was stained but extensive wood decay did not develop. While the wood in a living tree is protected from microbial attack by both periderm and rhytidome (Pearce 1996), these tissues are effective barriers to entry of most potential pathogens, as are the cortex and phloem. Ambrosia beetles obstruct these defenses by carving holes through the bark and sapwood and by inoculating the tunnels with ambrosia fungus.

During 411 days of this experiment, extreme precipitation, drought, or cold that would accelerate or inhibit development of decay did not occur.

\section{CONCLUSIONS}

This is the first report that prevention of wood-boring insect attack and brood development by an insecticide affects decay progress and severity in California coast live oaks. The radial spread of fully developed decay was halted 
beneath the bark sprayed with permethrin. This may have a significant practical application for standing coast live oak infected with P. ramorum because it prevents successions of scolytid beetle attacks and decay development. Thus, the treated tree may be safer for the arborist to climb.

\section{LITERATURE CITED}

Bright, D.E., and R.W. Stark. 1973. The bark and ambrosia beetles of California: Scolytidae and Platypodidae. Bulletin of the California Insect Survey, Vol. 16. University of California Press, Berkeley, CA. 169 pp.

Environmental Systems Research Institute, Inc. (ESRI). 2004. ArcGIS software. ESRI, Redlands, CA.

Farrell, B.D., A.S. Sequira, B.C. O’Meara, B.B. Normark, J.H. Chung, and B.H. Jordal. 2001. The evolution of agriculture in beetles (Curculionidae: Scolytinae and Platypodinae). Evolution 55(10):2011-2027.

Filip, G.M. 2001. Managing Tree Wounding and Stem Decay in Oregon Forests. The Woodland Workbook (EC 1519, April 2001). Oregon State University Extension, Corvallis, OR. 12 pp.

Furniss, R.L., and V.M. Carolin. 1978. Western Forest Insects (Misc. Publ. USDA No.1339). USDA Forest Service, Washington, DC. 654 pp.

Griffin, D. M. 1977. Water potential and wood-decay fungi. Ann. Rev. Phytopathol. 15:319-329.

Kaarick, A.A. 1974. Decomposition of wood, pp 120-174. In Biology of Plant Litter Decomposition. Dickinson, C.H., and G.J.F. Pugh (Eds.). Academic Press, New York, NY.

McPherson, B.A., D.L. Wood, A.J. Storer, P. Švihra, D.M. Rizzo, N.M. Kelly, and R.B. Standiford. 2000. Oak mortality syndrome: Sudden death of oaks and tanoaks. Tree Notes, Issue 2b. California Department of Forestry and Fire Protection.

Ostry, M.E., and N.A. Anderson.1998. Interactions of Insects, Woodpeckers, and Hypoxylon Canker on Aspen. USDA Forest Service Research Paper NC 331. 15 pp.

Pearce, R.B. 1996. Antimicrobial defenses in the wood of living trees. New Phytologist 132(2):203-233.

Rizzo, M.D., and M. Garbelotto. 2003. Sudden oak death: endangering California and Oregon forest ecosystems. Front Ecol Environ 1(5):197-204.

Rizzo, D.M., M. Garbelotto, J.M. Davidson, G.W. Slaughter, and S.T. Koike. 2002. Phytophthora ramorum as the cause of extensive mortality of Quercus spp. and Lithocarpus densiflorus in California. Plant Dis. 86:205-214.

Storer, A.J., K.E. Keirnan, N.K. Palkovsky, B.W. Hagen, G.W. Slaughter, N.M. Kelly, and P. Švihra. 2002. Diagnosis and Monitoring of Sudden Oak Death. UC Cooperative Extension Pest Alert \#6, March. 13 pp.
Švihra, P. 1999a. Western Oak Bark Beetles and Ambrosia Beetles, Killers of Live Oaks. UC Cooperative Extension Pest Alert \#3A, October. 4 pp.

1999b. Sudden Death of Tanoak, Lithocarpus densiflorus. UC Cooperative Extension Pest Alert \#1, June. $2 \mathrm{pp}$.

. P. 2001. Diagnosis of SOD: Case study of a scientific process. Calif. Agric. 55(1):12-13.

P. 2004. Not so fast. Amer. Nurseryman 199(9):62-67.

Švihra, P., D.F. Crosby, and B. Duckles. 2004. Emergence suppression of bark and ambrosia beetles in infested oaks. J. Arboric. 30(1):62-66.

Swiecki, T.J. and E.A. Bernhardt. 2003. Relationships between Phytophthora ramorum canker (sudden oak death) and failure potential in coast live oak.

Phytosphere Research, Vacaville, CA. Prepared for USDA Forest Service, Pacific Southwest Research Station, Berkeley, CA www.phytosphere.com/publications/ P_ramorum_coast_live_oak_failure_report_Oct_2002.pdf (accessed 9/27/04).

Swiecki, T.J., E.A. Bernhardt, and R.A. Arnold. 1997. The California oak disease and arthropod (CODA) database, pp 543-552. In Proceedings of a Symposium on Oak Woodlands: Ecology, Management, and Urban Interface Issues. Gen. Tech. Rep. PSW-GTR-160. USDA Forest Service Pacific Southwest Research Station, Albany, CA.

Acknowledgments. We gratefully acknowledge Bill Johnson, park maintenance supervisor, and his crew at the City of Novato, California, for providing the study site and assistance in establishing and sampling of trees. We appreciate the reviews and suggestions offered by Dr. T.T. Kozlowski and Dr. C.S. Koehler, as well as statistical advice from Dr. Nadir Erbilgin, the University of California, Berkeley.

${ }^{1 *}$ Horticulture Advisor

University of California Cooperative Extension

1682 Novato Blvd., Suite 150B

Novato, CA 94947, U.S.

${ }^{2}$ Specialist

Ecosystem Sciences Division

Environmental Sciences, Policy and Management Department

University of California

Berkeley, CA 94720, U.S.

*Corresponding author. 
Zusammenfassung. Die Attacken des EichenambrosiaKäfers beschleunigten und verstärkten den Anteil an Faulstellen in den Stämmen von Quercus agrifolia. Als das Insektizid Permithrin auf die Borke der Eichen gespritzt wurde, produzierte der Ambrosiakäfer nur ein Viertel der Gänge im Splintholz im Vergleich zu ungespritzten Eichen. Obwohl fäulniserregende Pilze in Abwesenheit der Käfer eine Infektion in den Eichen verursachen, war der Anteil an Holzfäule in Bäumen mit Käferaktivitäten viel größer. Der Ambrosiakäfer dringt tief in das Splintholz und konstruiert ausgedehnte Gallerien, die Fäule durch Fäulniserreger beschleunigen. Das Insektizid hemmte die Käferattacke und Formation von Eiergelegen und reduzierte deutlich die Fäule.

Resumen. Los ataques por el escarabajo ambrosia del encino (Monothrum scutellare) aceleraron e incrementaron la cantidad de decaimiento en la madera en tallos de encinos costeros (Quercus agrifolia). Cuando se hizo aspersión superficial con insecticida Permithrin en la corteza de los árboles, los escarabajos produjeron solamente una cuarta parte de galerías en la albura, comparada con la de encinos no tratados. A pesar de que se había iniciado la infección por decaimiento en los encinos en la ausencia de los escarabajos, la cantidad de madera descompuesta fue mayor en árboles con actividad de los escarabajos. Los escarabajos penetraron profundamente en la albura y construyeron extensas galerías que propiciaron el decaimiento de la madera por patógenos. El insecticida inhibió el ataque del escarabajo y la formación de galerías de huevos y disminuyó significativamente la cantidad de madera descompuesta.

Résumé. Les attaques par le scolyte du chêne (Monothrum scutellare) accélèrent et augmentent la quantité de bois carié dans les tiges des chênes verts de Californie (Quercus agrifolia). Lorsque l'insecticide permithrin était vaporisé sur la surface de l'écorce des chênes, les scolytes produisaient seulement le quart de leurs nombreuses galeries dans le bois d'aubier, et ce comparativement au bois d'aubier d'arbres dont l'écorce était non vaporisée. Même si les champignons de carie initient des infections sur le chêne en l'absence des scolytes, la quantité de bois carié était beaucoup plus importante chez les arbres avec une activité de scolytes. Les scolytes pénétraient profondément dans le bois d'aubier et creusaient des galeries très étendues qui accéléraient la carie du bois par les champignons pathogènes. Linsecticide inhibait l'attaque par les scolytes et la formation de galeries de ponte tout en diminuant la quantité de bois carié. 